\title{
Effect of Net Charge on DNA-Binding, Protein-Binding and Anticancer Properties of Copper(I) Phosphine-Diimine Complexes
}

\author{
Sammar Alsaedi ${ }^{1} \cdot$ Bandar A. Babgi $^{1}$ (D) Magda H. Abdellatif ${ }^{2} \cdot$ Abdul-Hamid Emwas $^{3} \cdot$ Mariusz Jaremko $^{4}$. \\ Mark G. Humphrey ${ }^{5}$. Mostafa A. Hussien ${ }^{1,6}$
}

Received: 4 March 2021 / Accepted: 25 June 2021 / Published online: 7 July 2021

(c) The Author(s) 2021

\begin{abstract}
The syntheses of $\left[\mathrm{Cu}\left(\mathrm{PPh}_{3}\right)_{2}(\mathrm{~L})\right] \mathrm{NO}_{3}$ and $\left[\mathrm{Cu}\left(\mathrm{PPh}_{3}\right)_{2}\left(\mathrm{~L}-\mathrm{SO}_{3} \mathrm{Na}\right)\right] \mathrm{NO}_{3}$ were achieved through the reaction of $\mathrm{Cu}\left(\mathrm{PPh}_{3}\right)_{2} \mathrm{NO}_{3}$ and equimolar amount of the ligands ( $\mathrm{L}=5,6$-diphenyl-3-[2-pyridyl]-1,2,4-triazine; $\mathrm{LSO}_{3} \mathrm{Na}=5$,6-diphenyl-3-[2-pyridyl]1,2,4-triazine-4,4'-disulfonic acid disodium salt). The complexes were characterized by NMR and IR spectroscopy and mass spectrometry. The compounds exhibit similar absorption and emission spectra, suggesting a similar electronic structure. Ct-DNA binding studies show the strong influence of the net charge as $\mathrm{Cu}-\mathrm{L}$ (positively charged) is able to bind to ct-DNA while $\mathrm{Cu}-\mathrm{LSO}_{3} \mathrm{Na}$ (negatively charged) is not. The net charge of the complexes affects the thermodynamic and kinetic binding parameters toward human serum albumin. HSA-binding of the complexes was further investigated by molecular docking, revealing different binding sites on the HSA protein as a function of the net charge. The different anticancer activities of the complexes towards ovcar-3 and hope-62 cancer cell lines are suggestive of a role for the overall charge of the complexes. Interaction with the DNA is not the major mechanism for this class of complexes. The overall net charge of the pharmacophore (anticancer agent) should be a key consideration in the design of anticancer metal complexes.
\end{abstract}

Keywords Copper(I) $\cdot$ Dipyridophenazine $\cdot$ DNA-binding $\cdot$ Anticancer properties $\cdot$ Molecular docking

\section{Introduction}

Bandar A. Babgi

bbabgi@kau.edu.sa

1 Department of Chemistry, Faculty of Science, King Abdulaziz University, P.O. Box 80203, Jeddah 21589, Saudi Arabia

2 Chemistry Department, Deanship of Scientific Research, College of Sciences, Taif University, P.O. Box 11099, Al-Haweiah Taif 21944, Saudi Arabia

3 Core Labs, King Abdullah University of Science and Technology (KAUST), Thuwal 23955-6900, Saudi Arabia

$4 \quad$ Biological and Environmental Science and Engineering (BESE), King Abdullah University of Science and Technology (KAUST), Thuwal 23955-6900, Saudi Arabia

5 Research School of Chemistry, Australian National University, Canberra, ACT 2601, Australia

6 Department of Chemistry, Faculty of Science, Port Said University, Port Said 42521, Egypt
Several transition-metal complexes, mainly containing platinum, have been approved or are currently in clinical trials for chemotherapy. Cisplatin is one of the most widespread chemotherapeutic drugs, being used in $50 \%$ of the chemotherapeutic treatment regimes, but its severe side effects have motivated further research efforts to develop alternatives [1-3]. Carboplatin and oxaliplatin have been approved (by the FDA) for clinical use while nedaplatin, lobaplatin, and heptaplatin have gained approval for clinical use [4]. Another strategy for the design of chemotherapeutic agents has involved the use of different metals, such as ruthenium, palladium and gold [5-7]. Promising coordination compounds of copper(I) and copper(II) have been examined as candidates in cancer therapy, aiming for less toxic compounds than platinum compounds with comparable or better activities (because copper is an essential trace element in biological systems) [8-10]. In particular, the interest in copper(I) complexes with mixed phosphine/diimine ligand sets has been growing tremendously. Recent research has confirmed the role of the diimine ligands in improving 
the cytotoxic properties of the copper complexes. A set of copper(I) complexes of the type $\left[\mathrm{CuX}\left(\mathrm{N}^{\wedge} \mathrm{N}\right)\right.$ (tris-(2-cyanoethyl)phosphine)] has been synthesized and evaluated for their in vitro antineoplastic properties against several cancer cell lines, highlighting that the most effective complex was the one with a dipyrido-[3,2-d:2',3'-f]-quinoxaline ligand [11]. In another study, a set of complexes with the general formula $\left[\mathrm{CuBr}\left(\mathrm{PPh}_{3}\right)\left(\mathrm{N}^{\wedge} \mathrm{N}\right)\right]$ was examined for their anticancer activities, the authors concluding that complexes with 3-[2-pyridyl]-5,6-diphenyl-1,2,4-triazine and dipyrido[3,2a:2',3'-c]phenazine (dppz) exhibited better cytotoxicity against several cancer cell lines than complexes with substituted phenanthroline and bipyridines [12]. Moreover, functionalizing the dppz ligand with groups such as nitro, cyano, methyl, etc., has been shown to alter the anticancer properties significantly, proving the critical role of the diimine ligands in the biological properties [13]. Other reports have examined the effect of incorporating hydrophilic phosphines such as tris(hydroxymethyl)phosphine $[14,15]$ and $N$-methyl-1,3,5-triaza-7-phosphaadamantane [16]; these limited studies have concluded that the water-soluble complexes have good anticancer activities with improved physiochemical properties. Copper(I) complexes including diimine ligands with water-solubilizing groups have also been examined for their in vitro anticancer potential against human tumor cell lines, exhibiting moderate to high cytotoxic activities and with potential to overcome cisplatin resistant cell lines [17]. Other strategies employed to improve the delivery of chemotherapy include functionalization of the drug with ester or carboxylic acid moieties [18-20], assembling $\mathrm{pH}$ - or temperature-responsive multilayer polymers encapsulating drugs [21-23], and encapsulating drugs in nanosheets [24] or metal-organic frameworks [25].

As mentioned above, the use of 5,6-diphenyl-3-[2pyridyl]-1,2,4-triazine (L) as a ligand in $\mathrm{CuBr}\left(\mathrm{PPh}_{3}\right)(\mathrm{L})$ improves the anticancer activities. In this work, water-solubilizing sodium sulfonate units were incorporated into the 5,6-diphenyl-3-[2-pyridyl]-1,2,4-triazine ligand (affording $\mathrm{L}-\mathrm{SO}_{3} \mathrm{Na}$ ). Two complexes were synthesized with the formula $\left[\mathrm{Cu}\left(\mathrm{PPh}_{3}\right)_{2}(\mathrm{~L})\right] \mathrm{NO}_{3}$ and $\left[\mathrm{Cu}\left(\mathrm{PPh}_{3}\right)_{2}\left(\mathrm{~L}-\mathrm{SO}_{3} \mathrm{Na}\right)\right] \mathrm{NO}_{3}$, and the DNA-binding, protein-binding and anticancer activities were evaluated to assess the role of the complex net charge.

\section{Experimental Section}

\subsection{Chemicals and Reagents}

Solvents (HPLC grade) were used as received. Calf thymus DNA (Type I) and human serum albumin were purchased from Sigma-Aldrich. 5,6-Diphenyl-3-(2-pyridyl)-1,2,4-triazine (L) and 5,6-diphenyl-3-(2-pyridyl)-1,2,4-triazine-4,4'-disulfonic acid disodium salt hydrate $\left(\mathrm{L}-\mathrm{SO}_{3} \mathrm{Na}\right)$ were purchased from Alfa Aesar. The synthesis of $\mathrm{Cu}\left(\mathrm{PPh}_{3}\right)_{2} \mathrm{NO}_{3}$ was achieved as described in the literature, by stirring copper(II) nitrate hemi(pentahydrate) with ca. three molar equivalents of triphenylphosphine in ethanol at reflux under a nitrogen gas atmosphere. The desired compound precipitated after a few minutes and was obtained by filtration as a white powder [26].

\subsection{Instrumentation}

Infrared spectra were recorded for powder samples of the compounds, using a Bruker Alpha FT-IR; peaks are reported in $\mathrm{cm}^{-1}$. ${ }^{1} \mathrm{H}$ NMR $(600 \mathrm{MHz})$ and ${ }^{31} \mathrm{P}$ NMR $(242 \mathrm{MHz})$ spectra were recorded using a Bruker Avance $600 \mathrm{MHz}$ spectrometer equipped with a BBO probe (BrukerBioSpin, Rheinstetten, Germany). The spectra were recorded using previously reported parameters [27]. High-resolution electrospray ionization (ESI) mass spectra were recorded using an Agilent Q-TOF 6520 instrument; all mass spectrometry data are reported as $m / z$. Absorption spectroscopy was performed using a Genesys-10 s UV-VIS spectrophotometer and $1 \mathrm{~cm}$ path-length quartz cells; bands are reported in the form wavelength (nm). Emission spectra were collected in $1 \mathrm{~cm}$ quartz cells using a Hitachi F-7000 fluorescence spectrometer.

\subsubsection{Synthesis of $\left[\mathrm{Cu}\left(\mathrm{PPh}_{3}\right)_{2}(\mathrm{~L})\right](\mathrm{Cu}-\mathrm{L})$}

A mixture of $\mathrm{Cu}\left(\mathrm{PPh}_{3}\right)_{2} \mathrm{NO}_{3}(600 \mathrm{mg}, 0.922 \mathrm{mmol})$ and 3-(2-pyridyl)-5,6-diphenyl-1,2,4-triazine (286 mg, $0.922 \mathrm{mmol})$ in dichloromethane $(15 \mathrm{~mL})$ was stirred for $2 \mathrm{~h}$ under a nitrogen atmosphere. The reaction solution was reduced in volume, diethyl ether was added, and the orange precipitate was collected by filtration, washed with petrol, and dried, affording complex $\mathbf{C u}-\mathbf{L}$ as an orange powder (420 mg, 51\%). IR (solid, cm ${ }^{-1}$ ): $3050 \mathrm{w}, 1597 \mathrm{w}, 1509 \mathrm{w}$, 1479 m, 1434 m, 1410 w, 1342 br, 1182 w, 1158 w, 1095 m, 1025 w, 997 w, 829 w, 797 w, 7706 m, 769 s, 744 s, 602 s, 644 w, 618 w. ${ }^{1} \mathrm{H}$ NMR $\left(\mathrm{CDCl}_{3}, 600 \mathrm{MHz}, 298 \mathrm{~K}\right): \delta 8.79$ (s br, $1 \mathrm{H}, \mathrm{py}), 8.50$ (s br, $1 \mathrm{H}, \mathrm{py}), 8.31$ (s br, $1 \mathrm{H}, \mathrm{py}), 7.78$ (s br, 1H, py), 7.62 (d, $\left.\mathrm{J}_{\mathrm{HH}}=6 \mathrm{~Hz}, 2 \mathrm{H}, \mathrm{Ph}\right), 7.52$ (s br, 2H, Ph), 7.44 (s br, 4H, Ph), 7.31 (s br, 6H, p-Ph $\mathrm{PPh}_{3}$ ), 7.16 (s br, 24H, $\left.\mathrm{PPh}_{3}\right) \cdot{ }^{31} \mathrm{P}\left\{{ }^{1} \mathrm{H}\right\}$ NMR $\left(\mathrm{CDCl}_{3}, 600 \mathrm{MHz}, 298 \mathrm{~K}\right): 3.17$ $\left(\mathrm{s}, \mathrm{PPh}_{3}\right)$. HR ESI MS: calcd for $\left[\mathrm{C}_{38} \mathrm{H}_{29} \mathrm{CuN}_{4} \mathrm{P}\right]^{+}\left[\mathrm{M}-\mathrm{PPh}_{3}\right]$ +635.1425 , found 635.14201 .

\subsubsection{Synthesis of $\left[\mathrm{Cu}\left(\mathrm{PPh}_{3}\right)_{2}\left(\mathrm{~L}-\mathrm{SO}_{3} \mathrm{Na}\right)\right]\left(\mathrm{Cu}-\mathrm{LSO}_{3} \mathrm{Na}\right)$}

$\mathrm{Cu}\left(\mathrm{PPh}_{3}\right)_{2} \mathrm{NO}_{3}(503 \mathrm{mg}, 770 \mathrm{mmol})$ and $\mathbf{L S O}_{\mathbf{3}} \mathbf{N a}(0.398 \mathrm{~g}$, $770 \mathrm{mmol})$ were stirred in a mixture of acetonitrile $(10 \mathrm{~mL})$ and methanol $(5 \mathrm{~mL})$ with a few drops of water for $2 \mathrm{~h}$ under a nitrogen atmosphere. The reaction solution was reduced in volume, diethyl ether was added, and the orange precipitate 
was collected by filtration, washed with petrol, and dried, affording complex $\mathbf{C u}-\mathbf{L S O}_{3} \mathbf{N a}$ as an orange powder (262 mg, 31\%). IR (solid, $\mathrm{cm}^{-1}$ ): 3459 br, $3055 \mathrm{w}, 1638 \mathrm{~m}$, 1597 w, 1511 w, 1480 m, 1435 m, 1393 w, 1365 m, 1196 br, 1156 m, 1117 m, 1096 m, 1033 s, 996 w, 907 w, 800 m, 784 m, 746 s, 740 s, 650 w, 617 s, 574 w, 561 w. ${ }^{1} \mathrm{H}$ NMR $\left(\mathrm{CDCl}_{3}, 600 \mathrm{MHz}, 298 \mathrm{~K}\right): \delta 8.76\left(\mathrm{~d}, \mathrm{~J}_{\mathrm{HH}}=12 \mathrm{~Hz}, 1 \mathrm{H}, \mathrm{py}\right)$, $8.34\left(\mathrm{~d}, \mathrm{~J}_{\mathrm{HH}}=6 \mathrm{~Hz}, 2 \mathrm{H}, \mathrm{Ph}\right), 8.14\left(\mathrm{t}, \mathrm{J}_{\mathrm{HH}}=7 \mathrm{~Hz}, 1 \mathrm{H}, \mathrm{py}\right)$, 8.07 (s br, 1H, py), 7.99 (s br, 2H, Ph), $7.53\left(\mathrm{t}, \mathrm{J}_{\mathrm{HH}}=7 \mathrm{~Hz}\right.$, 1H, py), 7.26 (s br, 4H, Ph), 7.19 (s br, 6H, p-Ph $\mathrm{PPh}_{3}$ ), 7.06 (s br, $\left.24 \mathrm{H}, \mathrm{PPh}_{3}\right) .{ }^{31} \mathrm{P}\left\{{ }^{1} \mathrm{H}\right\} \mathrm{NMR}\left(\mathrm{CDCl}_{3}, 600 \mathrm{MHz}, 298 \mathrm{~K}\right)$ : $3.21\left(\mathrm{~s}, \mathrm{PPh}_{3}\right)$. HR ESI MS: calcd for $\left[\mathrm{C}_{38} \mathrm{H}_{27} \mathrm{CuN}_{4} \mathrm{O}_{6} \mathrm{PS}_{2}\right]^{+}$ $\left[\mathrm{M}-2 \mathrm{Na}-\mathrm{PPh}_{3}\right]{ }^{+}$839.02011, found 839.0287.

\subsection{DNA Binding Studies}

\subsubsection{Ethidium Bromide Fluorescence Quenching}

A solution containing $100 \mu \mathrm{M}$ ct-DNA and $10 \mu \mathrm{M}$ ethidium bromide (EtBr) was prepared in Tris- $\mathrm{HCl} / \mathrm{NaCl}$ buffer solution $(\mathrm{pH}=7.2)$. The ct-DNA-EtBr solution was incubated for $24 \mathrm{~h}$. The solution was then titrated with different amounts of each of the complexes in DMSO, maintaining the DMSO at ca. $5 \% \mathrm{~V} / \mathrm{V}$. The changes in the emission spectra of the solutions were followed in the range 500-700 nm upon excitation at $390 \mathrm{~nm}$ after incubating the complexes for $4 \mathrm{~min}$. The Stern-Volmer quenching constants $\left(K_{\mathrm{SV}}\right)$ were calculated employing the equation below:

$\frac{F_{0}}{F}=1+K_{s v}[$ Cu compound $]$

where $F_{o}$ and $F$ are the emission intensities in the absence and the presence of the samples, respectively. The [Cu compound] was plotted against $\left[F_{\delta} / F\right]$; the $\mathrm{K}_{\mathrm{SV}}$ value was equal to the slope [28, 29].

\subsubsection{Determination of Binding Mode by Viscometry}

An Ostwald viscometer was used to perform the viscosity measurements. $10 \mu \mathrm{L}$ amounts of copper complexes were added to solutions of ct-DNA in buffer during which the $[\mathrm{Cu}$ compound $] /[\mathrm{DNA}]$ ratio was maintained in the range 0.02 to 0.2 . The solutions were incubated for $5 \mathrm{~min}$ at $25^{\circ} \mathrm{C}$ in a water bath before measurements. Average time flow for the solutions were recorded (replicating the measurements four times). The relative viscosities $\left(\eta / \eta_{\mathrm{o}}\right)^{1 / 3}$ were plotted against $\left[\mathrm{Cu}\right.$ compound]/[DNA], where $\eta_{\mathrm{o}}$ and $\eta$ represent the specific viscosity of the ct-DNA and the ct-DNA-Cu compound mixture, respectively. The specific viscosity $\eta$ and $\eta_{\mathrm{o}}$ were obtained utilizing the relation $\left[\left(t-t_{b}\right) / t_{b}\right]$ where $t$ is the observed flow time and $t_{b}$ is the buffer solution flow time $[28,29]$.

\subsection{HSA Binding Studies}

A solution containing $30 \mu \mathrm{M}$ of human serum albumin (HSA) was prepared in Tris- $\mathrm{HCl} / \mathrm{NaCl}$ aqueous buffer system $(\mathrm{pH}=7.4)$. The solution was titrated with different concentrations of both complexes in DMSO (the amount of DMSO was maintained at ca. $20 \% \mathrm{~V} / \mathrm{V}$ ). The changes in the emission spectra of the solutions were monitored at around $330 \mathrm{~nm}$ upon excitation at $270 \mathrm{~nm}$, after incubating the complexes for $4 \mathrm{~min}$ at $295 \mathrm{~K}$. The Stern-Volmer quenching constants $\left(\mathrm{K}_{\mathrm{SV}}\right)$ were calculated using Eq. 1 where $F_{o}$ and $F$ are the emission intensities of the protein in the absence and the presence of the complexes, respectively. The $[\mathrm{Cu}$ compound] was plotted against $\left[F_{d} / F\right]$; the $\mathrm{K}_{\mathrm{SV}}$ value was equal to the slope [30].

Binding constant $\left(\mathrm{K}_{\mathrm{b}}, \mathrm{M}^{-1}\right)$, and the number of binding sites (n) were calculated by plotting $\log \left[F_{o}-F / F\right]$ against $\log$ [Cu compounds] where the slope equals $\mathrm{n}$ and the intercept equals $\log K_{\mathrm{b}}$, as can be expressed in Eq. 2 [31].

$\log =\frac{F_{0}-F}{F} \log K_{b}+n \log [$ Cu compound $]$

The binding constant $\left(K_{\mathrm{b}}, \mathrm{M}^{-1}\right)$ can be used to calculate the change in Gibbs free energy $\left(\Delta \mathrm{G}^{0}\right)$ from the following equation [31, 32]:

$\Delta G^{0}=-R \cdot T \cdot \ln K_{b}$

\subsection{Molecular Docking}

The structure of the HSA receptor was downloaded from the protein data bank (PDB: 1H9Z) (http://www.rcsb.org/ $\mathrm{pdb} /$ home/home.do) [33]. The two synthesized compounds were sketched in ChemBioOffice Ultra, version 13. All docking studies used the MOE program. HSA (1H9Z) was prepared by removing all water and cofactor molecules from the downloaded proteins. Then, all invalid charges and broken bonds were corrected, and all hydrogen atoms were added. The parameters and charges were assigned with the MMFF94x force field. After alpha-site spheres were identified using the site finder module of MOE, the two complexes were docked to the same active site of the downloaded compound using the DOCK module of MOE [34, 35]. The docking scores in MOE software were obtained using the London $\mathrm{dG}$ scoring function. The highest ten docking scores were used to compare between the two complexes and the cocrystallized reference compound; the values were optimized using two independent refinement methods. The docking results were validated following the reported method [36, 37]. The method (the pose selection method) involves redocking the co-crystallized ligand into the receptor's active site. If the program is able to identify the best pose under 
a preselected Root Mean Square Deviation (RMSD) value from the known conformation (regularly 1.5 or $2 \AA$, depending on ligand size), the method is considered "validated". In the current study, pose selection and docking score for $\mathrm{R}$-warfarin (the co-crystallized compound with $1 \mathrm{H} 9 \mathrm{Z}$ ) were determined; the docking result of the same compound reached a $1.09 \AA$ A resolution of the co-crystal structure.

\subsection{Anticancer Studies}

The cells were supplied by the Egyptian Holding Company for Biological Products and Vaccines (VACSERA) and then kept in the tissue culture unit. The growth of the cells was effected in RPMI-1640 medium, supplemented with $10 \%$ heat inactivated FBS, 50 units/mL of penicillin, and $50 \mathrm{mg} / \mathrm{mL}$ of streptomycin, and maintained in a humidified atmosphere with $5 \%$ carbon dioxide $[38,39]$. The cells were maintained as monolayer cultures by serial sub-culturing, with cell culture reagents obtained from Lonza (Basel, Switzerland). The antitumor activities of the complexes were assessed against OVCAR-3 (ovarian cancer) and HOPE-62 (small cell lung cancer) cell lines.

The sulforhodamine B (SRB) assay method was applied to determine the cytotoxicity, as described in the literature [40]. Exponentially-growing cells were collected using $0.25 \%$ Trypsin-EDTA and seeded in 96-well plates at 1000-2000 cells/well in RBMI-1640 supplemented medium. The cells were kept in the medium for $24 \mathrm{~h}$ and then they were incubated for 3 days with various concentrations of the copper complexes. Following 3 days of treatment, the cells were fixed with $10 \%$ trichloroethanoic acid for $1 \mathrm{~h}$ at $4{ }^{\circ} \mathrm{C}$. Wells were stained for $10 \mathrm{~min}$ at room temperature with $0.4 \%$ SRBC dissolved in $1 \%$ acetic acid. The plates were air dried for $24 \mathrm{~h}$ and the dye was dissolved in Tris- $\mathrm{HCl}$ for 5 min with shaking at $1600 \mathrm{rpm}$. The optical density (OD) of each well was assessed spectrophotometrically at $564 \mathrm{~nm}$ with an ELISA microplate reader (ChroMate-4300, FL, USA). The $\mathrm{IC}_{50}$ values were calculated from a Boltzmann sigmoidal concentration response curve using the nonlinear regression fitting models (Graph Pad, Prism Version 9).

\section{Results and Discussion}

\subsection{Synthesis and Characterization}

An initial proposal was made to compare $\mathrm{CuBr}\left(\mathrm{PPh}_{3}\right)(\mathrm{L})$ against $\mathrm{CuBr}\left(\mathrm{PPh}_{3}\right)\left(\mathrm{L}-\mathrm{SO}_{3} \mathrm{Na}\right)$, but several problems were encountered in the synthesis of pure compound of the latter, including the existence of the ligand in two different coordination modes. Hence, we shifted our work to the synthesis of complexes of the formula $\left[\mathrm{Cu}\left(\mathrm{PPh}_{3}\right)_{2}\left(\mathrm{~N}^{\wedge} \mathrm{N}\right)\right]$ $\mathrm{NO}_{3}$. Copper(I) complexes were prepared as described in
Fig. 1, by reacting stoichiometric amounts of the ligands and $\mathrm{Cu}\left(\mathrm{PPh}_{3}\right)_{2} \mathrm{NO}_{3}$ under an inert gas atmosphere; the complexes were obtained in moderate yields. For the ligand 5,6-diphenyl-3-(2-pyridyl)-1,2,4-triazine-4,4'-disulfonic acid disodium salt hydrate $\left(\mathrm{L}-\mathrm{SO}_{3} \mathrm{Na}\right)$, the use of water was essential to dissolve the ligand, and hence we used acetonitrile/methanol mixture with a few drops of water to run the reaction. For 5,6-diphenyl-3-(2-pyridyl)-1,2,4-triazine, the reaction was performed in dichloromethane.

Both complexes reported in this work are stable at ambient conditions as solids or as solutions in chlorinated solvents or DMSO. The identities of the complexes were confirmed by ${ }^{1} \mathrm{H}$ and ${ }^{31} \mathrm{P}$ NMR spectroscopies as well as elemental analysis and mass spectrometry. In the ${ }^{31} \mathrm{P}$ NMR spectra, the compounds show intense singlet peaks around $-6 \mathrm{ppm}$. The mass spectra provided signals for $\left[\mathrm{M}-\mathrm{PPh}_{3}-\right.$ $\left.\mathrm{NO}_{3}\right]^{+}$in the case of $\mathbf{C u}-\mathrm{L}$ while the ion $\left[\mathrm{M}-\mathrm{PPh}_{3}-2 \mathrm{Na}\right.$ $\left.\mathrm{NO}_{3}\right]^{+}$was detected for $\mathbf{C u}-\mathbf{L S O}_{3} \mathbf{N a}$. The IR spectrum of $\mathbf{C u}-\mathrm{LSO}_{3} \mathrm{Na}$ confirms the presence of nitrate ion with the signal at $1365 \mathrm{~cm}^{-1}$. Electronic spectra of both compounds are almost identical, as both compounds exhibit an intense band at around $280 \mathrm{~nm}$ with a shoulder extending to ca. $370 \mathrm{~nm}$ (Fig. 2). The intense high energy bands are assigned as LC $\left(\pi-\pi^{*}\right)$ and the broad shoulder bands are attributed to $\operatorname{MLCT}\left(\mathrm{d}-\pi^{*}\right)[12,13,41]$. The emission spectra of the complexes were measured in deoxygenated DMSO solutions, with both compounds being excited at $370 \mathrm{~nm}$; the excitation wavelength was chosen experimentally by scanning in the proximity of the bands in the absorption spectra. The compounds have similar emission behavior with emission maxima at $420 \mathrm{~nm}$ and $450 \mathrm{~nm}$, with a shoulder extending to $550 \mathrm{~nm}$ (Fig. 2).

\subsection{DNA Binding Interactions}

Ethidium bromide is weakly emissive, the emission being enhanced when $\mathrm{EtBr}$ intercalates between the base pairs in the DNA, so the emissive EtBr-DNA adduct can be used as a good probe to evaluate the binding of single molecules. The fluorescence quenching of the ct-DNA-EtBr adduct was examined to assess the effect of the sodium sulfonate groups on the binding capabilities of the copper complex in the

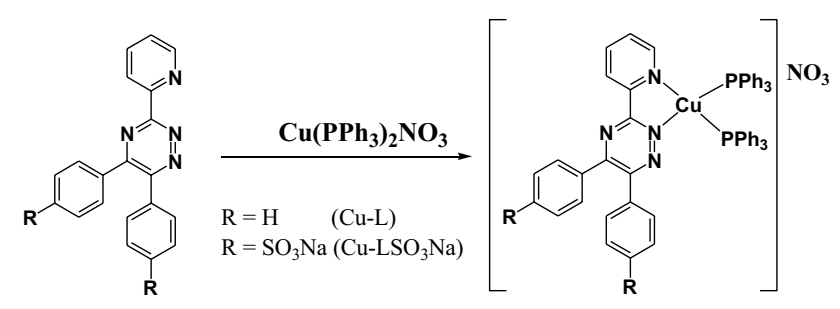

Fig. 1 Synthesis of $\mathrm{Cu}-\mathrm{L}$ and $\mathrm{Cu}-\mathrm{LSO}_{3} \mathrm{Na}$ 


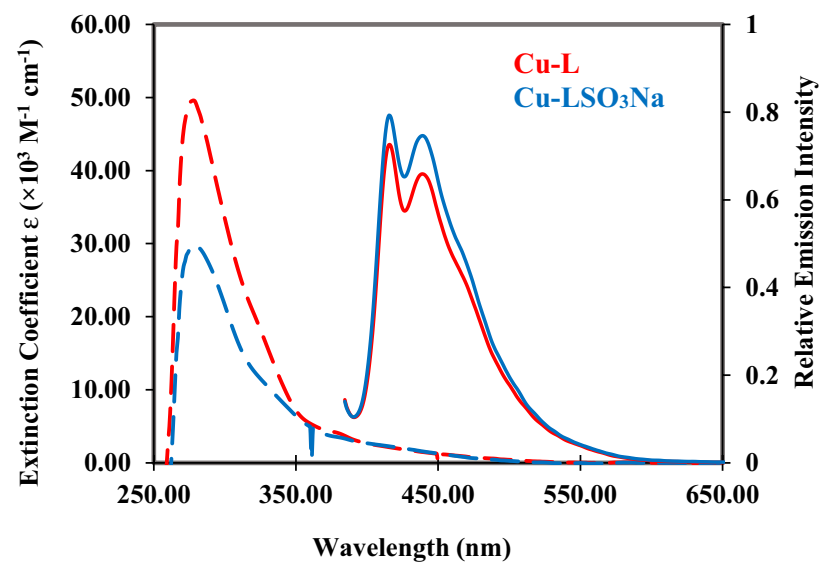

Fig. 2 Absorption and emission spectra of the copper compounds measured in DMSO solution $\left(2 \times 10^{-5} \mathrm{M}\right)$

ct-DNA binding process. The ability of the complexes to quench the EtBr-DNA system in this method is connected to the binding strength of the complexes to the DNA, and gives an indication about the mode of binding (the intercalation process) $[42,43]$. The concentration of the EtBr-DNA mixture was maintained at a constant value while the concentration of the complexes was increased by $20 \mu \mathrm{L}$ aliquots (Fig. 3). The titration process revealed that $\mathbf{C u}-\mathbf{L}$ partially quenches the ct-DNA-EtBr adduct while $\mathbf{C u}-\mathbf{L S O}_{3} \mathbf{N a}$ has no effect on the EtBr-DNA emission. This difference is due to the ability of $\mathbf{C u}-\mathbf{L}$ to bind to ct-DNA, displacing some of EtBr units and diminishing the emission intensity. In contrast, the presence of $\mathbf{C u}-\mathbf{L S O}_{3} \mathbf{N a}$ in the anionic form in the solution causes a repulsive interaction between the copper complex and the negatively charged ribose chain of ct-DNA.

The quenching process does not provide conclusive information on the binding mode. However, the trend in the changes of the viscosity of ct-DNA can indicate the compound-DNA binding mode $[42,43]$. Herein, the relative viscosity of ct-DNA has been monitored while increasing the concentrations of $\mathbf{C u}-\mathbf{L}$ and $\mathbf{C u}-\mathbf{L S O}_{3} \mathbf{N a}$, as well as ethidium bromide as a positive control for benchmarking (Fig. 4). The relative viscosity of the ct-DNA only increased appreciably when increasing the concentration of complex $\mathbf{C u}-\mathbf{L}$, while $\mathbf{C u}-\mathbf{L S O}_{3} \mathbf{N a}$ showed no pronounced change in the ct-DNA viscosity, which suggests either no interaction at all or groove binding [44]. Taking into consideration that $\mathrm{Cu}_{-} \mathbf{L S O}_{3} \mathbf{N a}$ has no effect on the ct-DNA-EtBr adduct, the complex is likely unable to bind to ct-DNA due to the overall negative charge of the complex that induces a repulsive effect with the negatively charged ribose phosphate chain [45].

\subsection{HSA Binding}

The interaction of chemotherapeutic agents with blood plasma proteins has been a subject of considerable interest in recent years due to their role in drug transport and metabolism, mainly with serum albumin (about 55\% of the blood plasma protein) [46, 47]. Figure 5 illustrates the interaction of complexes with HSA from the concentration dependence of the change in the fluorescence intensity (at $335-340 \mathrm{~nm}$ ) of the protein upon the addition of complexes at $295 \mathrm{~K}$. The characteristic broad emission band decreases dramatically with small additions of the complexes $(\mathbf{C u}-\mathbf{L}$

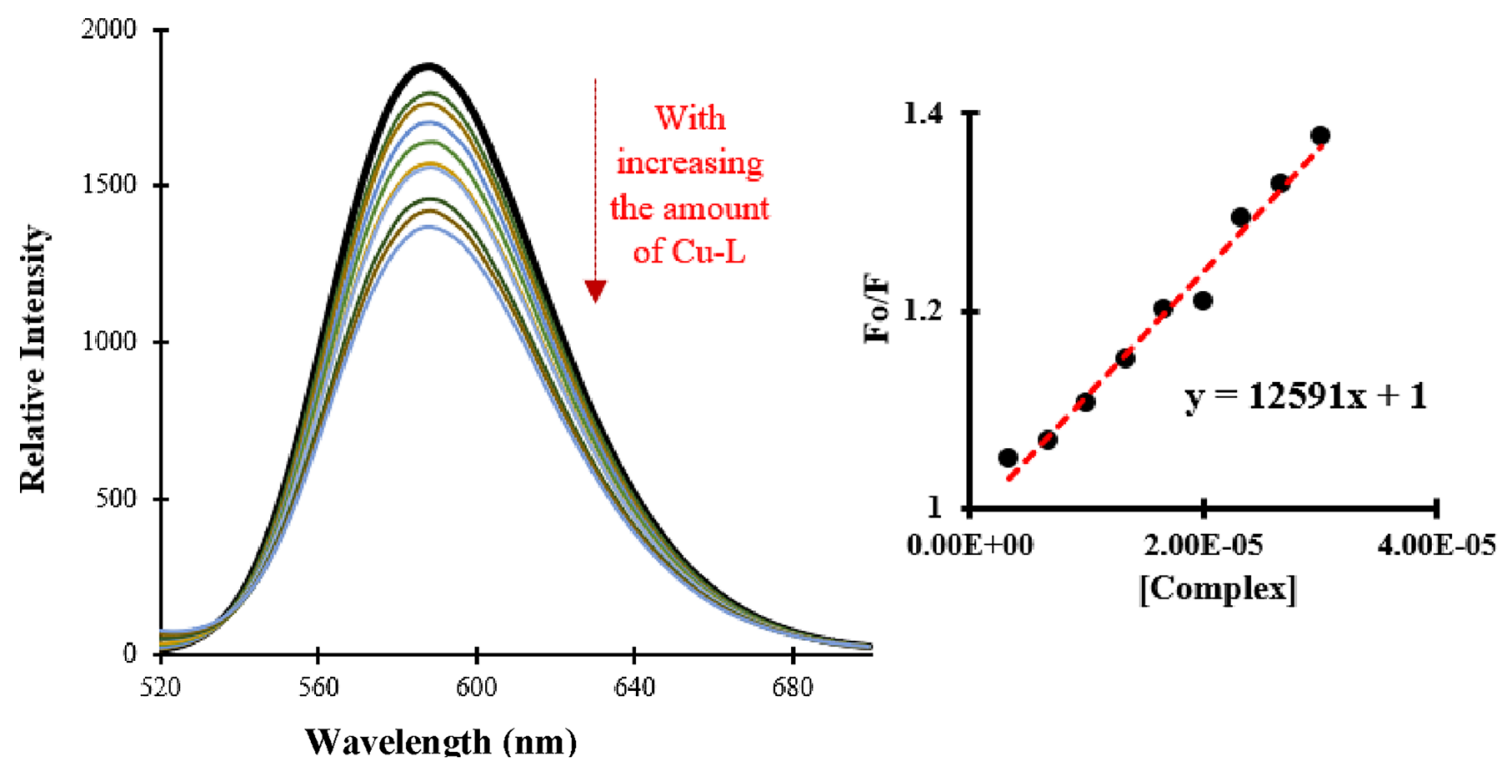

Fig. 3 Quenching of ct-DNA-EtBr emission upon titrating with increasing amounts of $\mathrm{Cu}-\mathrm{L}$ 


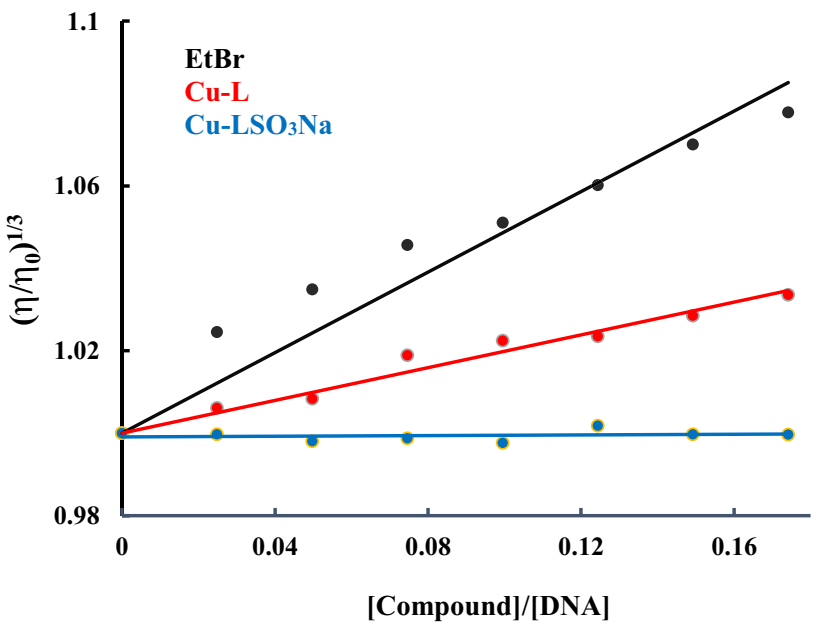

Fig. 4 Changes in the relative viscosity of ct-DNA with increasing amounts of ethidium bromide, $\mathrm{Cu}-\mathrm{L}$, and $\mathrm{Cu}-\mathrm{LSO}_{3} \mathrm{Na}$

and $\mathbf{C u}-\mathbf{L S O}_{3} \mathbf{N a}$ ), confirming the interaction between complexes and HSA. The fluorescence quenching is described by the Stern-Volmer equation (Eq. 1); the Stern-Volmer constant can be related to the quenching constant by the following equation:

$K_{\mathrm{sv}}=K_{\mathrm{q}} \times \tau_{0}$

where $\mathrm{k}_{\mathrm{q}}$ is the quenching rate constant and $\tau_{0}$ is the average fluorescence lifetime of the protein without the quencher $(\sim 7 \mathrm{~ns})[48,49]$. The data of the two complexes are summarized in Table 1. The quenching constants suggest the existence of the static quenching mechanism as our complexes have rates much higher than $2.00 \times 10^{10} \mathrm{M}^{-1} \mathrm{~s}^{-1}$ (the maximum value for dynamic quenching) [50]. From the Scatchard equation (Eq. 3), the binding constants were calculated, revealing that $\mathbf{C u}-\mathbf{L}$ exhibits higher binding
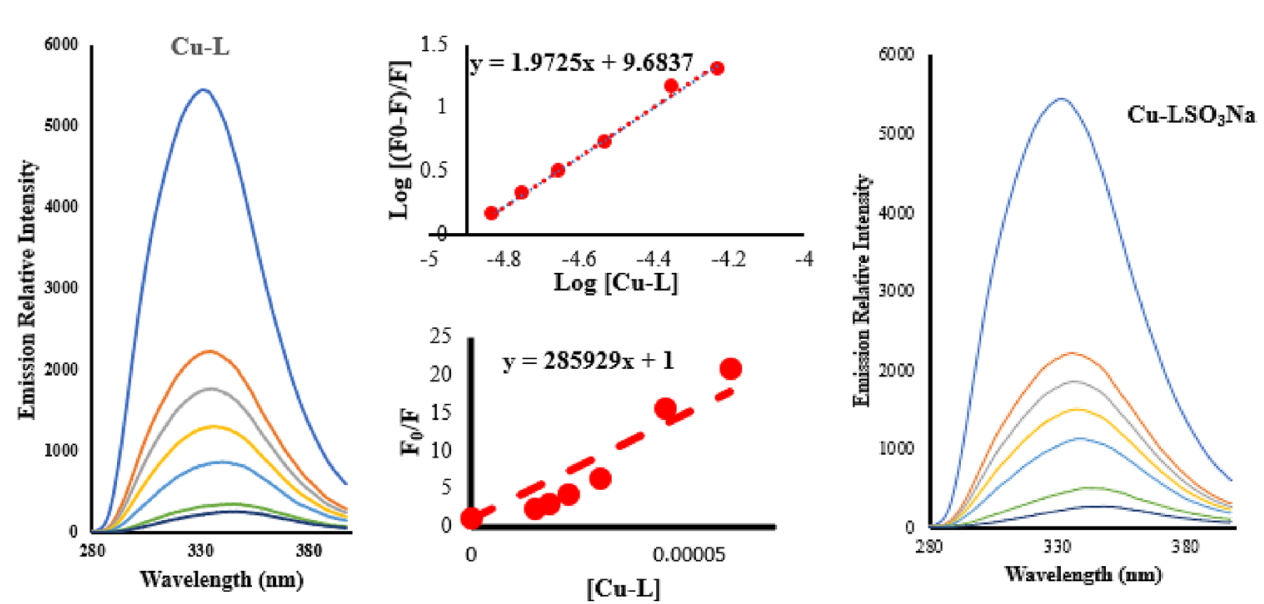
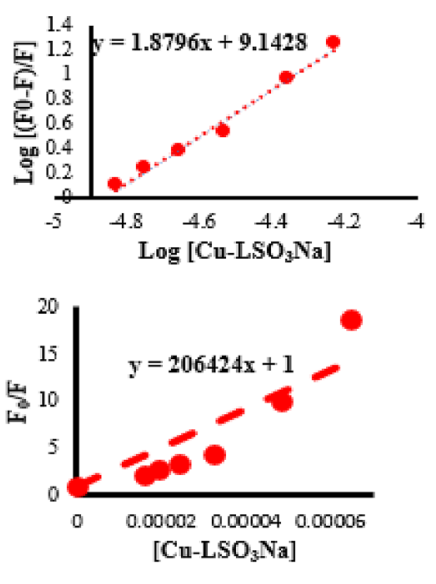

Table 1 Kinetic and thermodynamic parameters of the protein-compound binding at $295 \mathrm{~K}$

\begin{tabular}{llllll}
\hline Compound & $\mathrm{K}_{\mathrm{sv}}\left(\times 10^{5}\right)$ & $\mathrm{K}_{\mathrm{q}}\left(\times 10^{13}\right)$ & $\mathrm{K}_{\mathrm{b}}\left(\times 10^{9}\right)$ & $\mathrm{n}$ & $\begin{array}{l}\Delta \mathrm{G}^{0}(\mathrm{~kJ} \\
\left.\mathrm{mol}^{-1}\right)\end{array}$ \\
\hline $\mathrm{Cu}-\mathrm{L}$ & 2.86 & 4.08 & 4.83 & 1.97 & -54.9 \\
$\mathrm{Cu}-$ & 2.06 & 2.95 & 1.39 & 1.88 & -51.6 \\
$\mathrm{LSO}_{3} \mathrm{Na}$ & & & & & \\
\hline
\end{tabular}

constants for HSA than does $\mathbf{C u}-\mathbf{L S O}_{\mathbf{3}} \mathbf{N a}$ (Table 1). The average binding site count for the complexes is nearly 2 for HSA. Indeed, the number of binding sites is more accurately describing the stoichiometric ratio of the compounds to HSA [51]. HSA consists of three domains (DI, DII and DIII), of which two domains are primarily hydrophobic regions which can involve the binding of our complexes [47, 52, 53]. Both compounds showed negative values of $\Delta \mathrm{G}^{0}$, indicating the spontaneous interaction with this protein; $\mathbf{C u}-\mathbf{L}$ is "more spontaneous" than $\mathbf{C u}-\mathbf{L S O}_{3} \mathbf{N a}$ (Table 1).

\subsection{Molecular Docking}

A molecular docking study was undertaken to gain an understanding of the binding sites and possible interactions of the complexes in the protein environment [54, 55]. The lowest ten binding energies of the complexes were obtained, of which the best three are listed in Table 2 . In general, $\mathbf{C u}-\mathbf{L}$ has a better binding score toward HSA than that calculated for $\mathbf{C u}-\mathbf{L S O}_{\mathbf{3}} \mathbf{N a}$. The data indicate that $\mathbf{C u}-\mathbf{L}$ has a strong preference to bind at site 1 (in DII) (Fig. 6) while $\mathbf{C u}-\mathbf{L S O}_{3} \mathbf{N a}$ exclusively binds to site 2 (DIII) (Fig. 6). In site 1, the HSA pocket (DII) is surrounded by Glu153, Phe156, Phe157, Arg 160, Glu184, Glu188, Ala191, Ser192, Lys195, His 288, Glu292, Glu294, Lys436, His440 and Tyr452 amino acids; some of these amino acid residues are involved in the electrostatic,

Fig. 5 Protein binding studies of $\mathrm{Cu}-\mathrm{L}$ and $\mathrm{Cu}-\mathrm{LSO}_{3} \mathrm{Na}$ 
Table 2 Binding scores for $\mathrm{Cu}-\mathrm{L}$ and $\mathrm{Cu}-\mathrm{LSO}_{3} \mathrm{Na}$ as calculated by MOE

\begin{tabular}{lll}
\hline & Binding site & Binding score \\
\hline $\mathrm{Cu}-\mathrm{L}$ & Site1 & -7.63 \\
& Site1 & -6.79 \\
& Site 1 & -6.66 \\
$\mathrm{Cu}-\mathrm{LSO}_{3} \mathrm{Na}$ & Site 2 & -7.18 \\
& Site 4 & -6.92 \\
& Site 2 & -6.87 \\
\hline
\end{tabular}

hydrophobic and van der Waals interactions of $\mathbf{C u}-\mathbf{L}$, with the arginine, in particular, establishing cation-pi interactions. The HSA site 2 pocket (DIII) is on the face of an area consisting of the following amino acids: Asp108, Asn109, Pro110, Asn111, Leu112, Pro113, Arg 114, Arg145, Thr422, Glu425 and Leu463; Cu-LSO ${ }_{3}$ Na establishes electrostatic, hydrophobic and van der Waals interactions with some of these amino acids. The dramatic difference in the binding sites with different amino acids for both complexes indicates the crucial nature of the overall net charge of the complexes. $\mathbf{C u}-\mathbf{L}$ with its net positive charge is able to squeeze into a pocket with negatively charged amino acids (glutamic acid and aspartic acid) while $\mathbf{C u}$ $\mathbf{L S O}_{3} \mathbf{N a}$ forms negatively charged species after dissolving in aqueous medium, and is consequently attracted towards the positively charged arginine amino acid.

\subsection{Anticancer Activities}

Both complexes were tested against ovcar-3 and hope62 cell lines. $\mathbf{C u}-\mathbf{L}$ has $\mathrm{IC}_{50}$ values of $11.07 \pm 0.39$ and $21.55 \pm 0.69$ while $\mathbf{C u}-\mathbf{L S O}_{3} \mathbf{N a}$ exhibits values of $14.59 \pm 0.77$ and $16.56 \pm 0.57$ against ovcar- 3 and hope62 , respectively. Comparing the values of both compounds suggests mechanisms involving no DNA binding because $\mathbf{C u}-\mathbf{L S O}_{3} \mathbf{N a}$ has cytotoxic effects comparable to $\mathbf{C u}-\mathbf{L}$ while it has no DNA-binding capability; indeed, the net charge seems to play a minor role in the anticancer activities. However, both complexes have less cytotoxic effect than $\mathrm{CuBr}\left(\mathrm{PPh}_{3}\right)(\mathrm{dppz}-11-\mathrm{CN})[13]$ or $\left[\mathrm{Cu}\left(\mathrm{PPh}_{3}\right)_{2}(\mathrm{dppz})\right]^{+}$ [30], which indicates that factors such as steric hindrance and hydrophobicity are more dominant in the anticancer activities of copper(I) complexes.

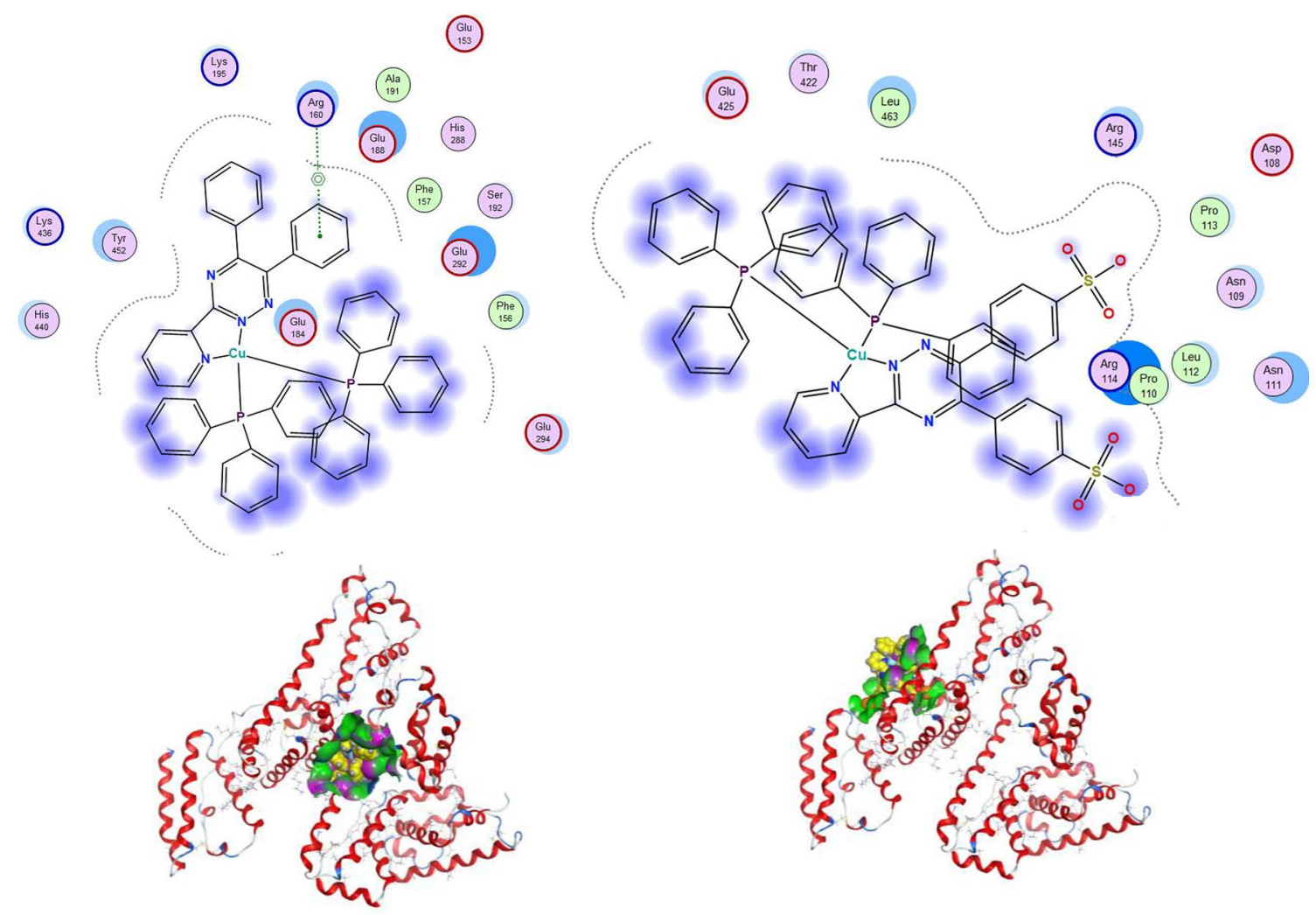

Fig. 6 Different interaction domains of $\mathrm{Cu}-\mathrm{L}$ and $\mathrm{Cu}-\mathrm{LSO}_{3} \mathrm{Na}$ with $\mathrm{HAS}$ 


\section{Conclusion}

Previous work has suggested that 5,6-diphenyl-3-[2pyridyl]-1,2,4-triazine (L) ligand enhances the anticancer activities of copper complexes of the formula $\mathrm{CuBr}\left(\mathrm{PPh}_{3}\right)$ $\left(\mathrm{N}^{\wedge} \mathrm{N}\right)$ [12]. In drug design, water-solubility is desirable and hence we sought to evaluate the impact of incorporating the water solubilizing groups sodium sulfonate (5,6-diphenyl-3-[2-pyridyl]-1,2,4-triazine-4,4'-disulfonic acid disodium salt) $\left(\mathrm{L}-\mathrm{SO}_{3} \mathrm{Na}\right)$ on the DNA-binding, HSA-binding and anticancer properties. $\left[\mathrm{Cu}\left(\mathrm{PPh}_{3}\right)_{2}(\mathrm{~L})\right]$ $\mathrm{NO}_{3}$ and $\left[\mathrm{Cu}\left(\mathrm{PPh}_{3}\right)_{2}\left(\mathrm{~L}-\mathrm{SO}_{3} \mathrm{Na}\right)\right] \mathrm{NO}_{3}$ were synthesized and characterized by NMR and IR spectroscopy and mass spectrometry. Absorption and emission spectra of the complexes are almost identical and hence they have minimal difference in their electronic properties. The major difference between the complexes is the net charge: the first complex exists as a cationic species in solution, while the second one possesses a negative-net charge. Ct-DNA binding studies show the strong influence of the net charge as $\mathbf{C u}-\mathbf{L}$ is able to bind to ct-DNA while $\mathbf{C u}-\mathbf{L S O}_{3} \mathbf{N a}$ is not. The net charge of the complexes causes different thermodynamic and kinetic binding capabilities toward human serum albumin. The compounds-HSA binding was further investigated by molecular docking; the two complexes show different preferred binding sites on the HSA protein as a function of their net charge. Finally, the cytotoxicity towards ovcar- 3 and hope-62 cancer cell lines reveal that the complexes have slight differences $( \pm 30 \%)$ in their cytotoxic effects, indicating that the net charge has some impact on the anticancer activities. However, it seems that DNA is not the major target for this class of complexes. In conclusion, water solubility is desirable, but consideration of the overall net charge of the pharmacophore (anticancer agent) must also be made.

Acknowledgements This project was funded by the Deanship of Scientific Research (DSR), King Abdulaziz University, Jeddah, Saudi Arabia, under grant no. (KEP-44-130-40). The authors, therefore, acknowledge with thanks DSR technical and financial support.

\section{Declarations}

Conflict of interest The authors declare that there is no conflict of interest regarding the publication of this paper.

Open Access This article is licensed under a Creative Commons Attribution 4.0 International License, which permits use, sharing, adaptation, distribution and reproduction in any medium or format, as long as you give appropriate credit to the original author(s) and the source, provide a link to the Creative Commons licence, and indicate if changes were made. The images or other third party material in this article are included in the article's Creative Commons licence, unless indicated otherwise in a credit line to the material. If material is not included in the article's Creative Commons licence and your intended use is not permitted by statutory regulation or exceeds the permitted use, you will need to obtain permission directly from the copyright holder. To view a copy of this licence, visit http://creativecommons.org/licenses/by/4.0/.

\section{References}

1. E. Wong, C.M. Giandomenico, Current status of platinum-based antitumor drugs. Chem. Rev. 99, 2451-2466 (1999)

2. C.A. Rabik, M.E. Dolan, Molecular mechanisms of resistance and toxicity associated with platinating agents. Cancer Treat. Rev. 33, 9-23 (2007)

3. P. Heffeter, U. Jungwirth, M. Jakupec, C. Hartinger, M. Galanski, L. Elbling, M. Micksche, B. Kepper, W. Berger, Resistance against novel anticancer metal compounds: differences and similarities. Drug Resist. Updates 11, 1-16 (2008)

4. N.P. Farrell, Multi-platinum anti-cancer agents. Substitution-inert compounds for tumor selectivity and new targets. Chem. Soc. Rev. 44, 8773-8785 (2015)

5. S. Medici, M. Peana, V.M. Nurchi, J.I. Lachowicz, G. Crisponi, M.A. Zoroddu, Noble metals in medicine: latest advances. Coord. Chem. Rev. 284, 329-350 (2015)

6. F. Trudu, F. Amato, P. Vaňhara, T. Pivetta, E.M. Peña-Méndez, J. Havel, Coordination compounds in cancer: past, present and perspectives. J. Appl. Biomed. 13, 79-103 (2015)

7. T. Lazarevic, A. Rilak, Z.D. Bugarcic, Platinum, palladium, gold and ruthenium complexes as anticancer agents: current clinical uses, cytotoxicity studies and future perspectives. Eur. J. Med. Chem. 142, 8-31 (2017)

8. C. Marzano, M. Pellei, F. Tisato, C. Santini, Copper complexes as anticancer agents. Anti-Cancer Agents Med. Chem. 9, 185-211 (2009)

9. I. Iakovidis, I. Delimaris, S.M. Piperakis, Copper and its complexes in medicine: a biochemical approach. Mol Biol. Int (2011). https://doi.org/10.4061/2011/594529

10. C. Santini, M. Pellei, V. Gandin, M. Porchia, F. Tisato, C. Marzano, Advances in copper complexes as anticancer agents. Chem. Rev. 114, 815-862 (2014)

11. V. Gandin, M. Porchia, F. Tistao, A. Zanella, E. Severin, A. Dolmella, C. Marzano, Novel mixed-ligand copper(I) complexes: role of diimine ligands on cytotoxicity and genotoxicity. J. Med. Chem. 56, 7416-7430 (2013)

12. B.A. Babgi, K.H. Mashat, M.H. Abdellattif, M.N. Arshad, K.A. Alzahrani, A.M. Asiri, J. Du, M.G. Humphrey, M.A. Hussien, Synthesis, structure, DNA-binding, cytotoxicity and molecular docking of $\mathrm{CuBr}\left(\mathrm{PPh}_{3}\right)$ (diimine). Polyhedron 192, 114847 (2020)

13. S. Alsaedi, B.A. Babgi, M.H. Abdellatif, M.N. Arshad, A. Emwas, M. Jaremko, M.G. Humphrey, A.M. Asiri, M.A. Hussein, DNAbinding and cytotoxicity of copper(I) complexes containing functionalized dipyridylphenazine ligands. Pharmaceutics 13, 764-764 (2021)

14. C. Marzano, M. Pellei, D. Colavito, S. Alidori, G.G. Lobbia, V. Gandin, F. Tisato, C. Santini, Synthesis, Characterization, and in Vitro Antitumor Properties of Tris(hydroxymethyl)phosphine Copper(I) Complexes Containing the New Bis(1,2,4-triazol-1-yl) acetate Ligand. J. Med. Chem. 49, 7317-7324 (2006)

15. C. Marzano, V. Gandin, M. Pellei, D. Colavito, G. Papini, G.G. Lobbia, E.D. Giudice, M. Porchia, F. Tisato, C. Santini, in vitro antitumor activity of the water soluble copper(I) complexes bearing the tris(hydroxymethyl)phosphine ligand. J. Med. Chem. 51, 798-808 (2008)

16. M. Porchia, F. Benetollo, F. Refosco, F. Tisato, C. Marzano, V. Gandin, Synthesis and structural characterization of copper(I) complexes bearing N-methyl-1,3,5-triaza-7-phosphaadamantane 
(mPTA): cytotoxic activity evaluation of a series of water soluble $\mathrm{Cu}(\mathrm{I})$ derivatives containing PTA, PTAH and mPTA ligands. J. Inorg. Biochem. 103, 1644-1651 (2009)

17. M. Porchia, F. Tisato, M. Zancato, V. Gandin, C. Marzano, In vitro antitumor activity of water-soluble copper(I) complexes with diimine and monodentate phosphine ligands. Arab. J. Chem. 13, 998-1010 (2020)

18. N. Fattahi, A. Ramazani, M. Hamidi, M. Parsa, K. Rostamizadeh, H. Rashidzadeh, Enhancement of brain delivery of methotrexate with administration of mid-chain ester prodrugs: in vitro and in vivo studies. Int. J. Pharmaceutics. 600, 120479 (2021)

19. N. Fattahi, A. Bahari, A. Ramazani, D. Koolivand, In vitro immunobiological assays of methotrexate-stearic acid conjugate in human PBMCs. Immunobiology 225, 151984 (2020)

20. N. Fattahi, M.-A. Shahbazi, A. Maleki, M. Hamidi, A. Ramazani, H.A. Santos, Emerging insights on drug delivery by fatty acid mediated synthesis of lipophilic prodrugs as novel nanomedicines. J. Controlled Release 326, 556-598 (2020)

21. L. Xu, Z. Chu, H. Wang, L. Cai, Z. Tu, H. Liu, C. Zhu, H. Shi, D. Pan, J. Pan, X. Fei, Electrostatically assembled multilayered films of biopolymer enhanced nanocapsules for on-demand drug release. ACS Appl. Bio. Mater. 2, 3429-3438 (2019)

22. L. Xu, H. Wang, Z. Chu, L. Cai, H. Shi, C. Zhu, D. Pan, J. Pan, X. Fei, X. Lei, Temperature-responsive multilayer films of micelle-based composites for controlled released of a third generation EGFR inhibitor. ACS Appl. Polym. Mater. 2, 741-750 (2020)

23. Y. Lu, A. Zhuk, L. Xu, X. Liang, E. Kharlampieva, S.A. Sukhishvili, Tunable $\mathrm{pH}$ and temperature response of weak polyelectrolyte brushes: role of hydrogen bonding and monomer hydrophobicity. Soft Matter 9, 5464-5472 (2013)

24. M. Razaghi, A. Ramazani, M. Khoobi, T. Mortezazadeh, E.A. Aksoy, Küçükilinç, Highly fluorinated graphene oxide nanosheets for anticancer linoleic-curcumin conjugate delivery and $\mathrm{T}_{2}$-weighted magnetic resonance imaging: in vitro and in vivo studies. J. Drug Del. Sci. Tech. 60, 101967 (2020)

25. A. Ebrahimpour, N.R. Alam, P. Abdolmaleki, B.H. Verdom, F. Tirgar, T. Ebrahimi, M. Khoobi, Magnetic metal-organic framework based on zinc and 5-aminolevulinic acid: MR imaging and brain tumor therapy. J. Inorg. Organomet. Polym. Mater. 31, 1208-1216 (2021)

26. Cotton, F. A.; Goodgame, D. I. L.; Tetrakis(triphenylphosphine)silver(I) and -copper(I) complexes. J. Chem. Soc. 1960, 5267-5269.

27. H.T. Al-Masri, A.M. Emwas, Z.A. Al-Talla, M.H. Alkordi, Synthesis and characterization of new $\mathrm{N}$-(diphenylphosphino)naphthylamine chalcogenides: X-ray structures of $\mathrm{C}_{10} \mathrm{H}_{6}-1-\mathrm{HN}(\mathrm{Se})$ $\mathrm{Ph}_{2}$ and $\mathrm{Ph}_{2} \mathrm{P}(\mathrm{S}) \mathrm{OP}(\mathrm{S}) \mathrm{Ph}_{2}$. Phosphorus Sulfur Silicon Relat. Elem. 187, 1082-1090 (2012)

28. C.S. Devi, B. Thulasiram, S. Satyanarayana, P. Nagababu, Analytical techniques used to detect DNA binding modes of ruthenium(II) complexes with extended phenanthroline ring. J. Fluoresci. 27, 2119-2130 (2017)

29. A. Erxleben, Investigation of non-covalent interactions of metal complexes with DNA in cell-free systems. Chimia 71, 102-111 (2017)

30. W. Villarreal, L. Colina-Vegas, G. Visbal, O. Corona, R.S. Correa, J. Ellena, M.R. Cominetti, A.A. Batista, M. Navarro, Copper(I)-phosphine polypyridyl complexes: synthesis, characterization, DNA/HAS binding study and antiproliferative activity. Inorg. Chem. 56, 3781-3793 (2017)

31. H. Lineweaver, D. Burk, The determination of enzyme dissociation constants. J. Am. Chem. Soc. 56, 658-666 (1934)

32. A.S. Abdelhameed, A.H. Bakheit, F.M. Almutairi, H. AlRabiah, A.A. Kadi, Biophysical and in silico studies of the interaction between the anti-viral agents acyclovir and penciclovir, and human serum albumin. Molecules 22, 1906 (2017)

33. I. Petitpas, A.A. Bhattacharya, S. Twine, M. East, S. Curryi, Crystal structure analysis of warfarin binding to human serum albumin. J. Biol. Chem. 276, 22804-22809 (2001)

34. N.D. Al-Khathami, K.S. Al-Rashdi, B.A. Babgi, M.A. Hussien, M.N. Arshad, N.E. Eltayeb, S.E. Elsilk, J. Lasri, A.S. Basaleh, M. Al-Jahdali, Spectroscopic and biological properties of platinum complexes derived from 2-pyridyl Schiff basses. J. Saudi Chem. Soc. 23, 903-915 (2019)

35. N.M. Hosny, M.H. Abdel-Rhman, M.A. Hussien, H.M. Mahmoud, Synthesis, characterization, molecular docking and cytotoxicity studies on N-benzyl-2-isonicotinoylhydrazine1-carbothioamide and its metal complexes. J. Molec. Struct. 1196, 417-428 (2019)

36. J.C. Cole, C.W. Murray, J.W. Nissink, R.D. Taylor, R. Taylor, Comparing protein-ligand docking programs is difficult. Proteins 60, 325-332 (2005)

37. A.N. Jain, Bias, reporting, and sharing: computational evaluations of docking methods. J. Comput. -Aided Mol. Des. 22, 201-212 (2008)

38. D.N. Muanza, B.W. Kim, K.L. Euler, L. Williams, Antibacterial and antifungal activities of nine medicinal plants of Zaire. Int. J. Pharmacog. 32, 337-345 (1994)

39. J.M. Pezzuto, C.-T. Che, D.D. McPherson, J.-P. Zhu, G. Topcu, C.A.J. Erdelmeier, G.A. Cordell, DNA as affinity probe useful in the detection and isolation of biologically active natural products. J. Natur. Prod. 54, 1522-1530 (1991)

40. P. Skehan, R. Storeng, D. Scudiero, A. Monks, J. McMahon, D. Vistica, J. Warren, H. Bokesch, S. Kenney, M.R. Boyd, New colorimetric cytotoxicity as anticancer drug screening. J. Natl. Cancer Inst. 82, 1107-1112 (1990)

41. A.N. Jadhav, S.B. Pawal, S.S. Chavan, Synthesis, crystal structure and conjugation properties of iminopyridine copper(I) phosphine complex. Inorg. Chim. Acta 440, 77-83 (2016)

42. Z. Molphy, A. Prisecaru, C. Slator, N. Barron, M. McCann, J. Colleran, D. Chandran, N. Gathergodd, A. Kellett, Copper phenanthrene oxidative chemical nucleases. Inorg. Chem. 53, 5392-5404 (2014)

43. T. Thirunavukkarasu, H.A. Sparkes, K. Natarajan, Quinoline based Pd(II) complexes: Synthesis, characterization and evaluation of DNA/protein binding, molecular docking and in vitro anticancer activity. Inorg. Chim. Acta 482, 229-239 (2018)

44. G. Baronea, A. Terenzi, A. Lauriaa, A.M. Almerico, J.M. Leal, N. Bustoc, B. Garcíac, DNA-binding of nickel(II), copper(II) and zinc(II) complexes: Structure-affinity relationships. Coord. Chem. Rev. 257, 2848-2862 (2013)

45. S.U. Rehman, Z. Yaseen, M.A. Husain, T. Sarwar, H.M. Ishqi, M. Tabish, Interaction of 6-mercaptopurine with calf thymus DNAdeciphering the binding mode and photoinduced DNA damage. PLOS One 9, e93913 (2014)

46. D. Gibellini, F. Vitone, P. Schiavone, C. Ponti, M.L. Placa, M.C. Re, Quantitative detection of human immunodeficiency virus type 1 (HIV-1) proviral DNA in peripheral blood mononuclear cells by SYBR green real-time PCR technique. J. Clin. Virol. 29, 282 (2004)

47. J.R. Lakowicz, Principles of Fluorescence Spectroscopy, 3rd edn. (Springer, New York, 2006)

48. M. Amiri, K. Jankeje, J.R. Albani, Origin of fluorescence lifetimes in human serum albumin. Studies on native and denatured protein. J. Fluor. 20, 651-656 (2010)

49. M. Amiri, K. Jankeje, J.R. Albani, Characterization of human serum albumin forms with $\mathrm{pH}$. Fluorescence lifetime studies. J. Pharm. Biomed. Anal. 51, 1097-1102 (2010) 
50. W.R. Ware, Oxygen quenching of fluorescence in solution: an experimental study of the diffusion process. J. Phys. Chem. B 66, 455-458 (1962)

51. E. Lissi, C. Calderon, A. Campos, Evaluation of the number of binding sites in proteins from their intrinsic fluorescence: limitations and pitfalls. Photochem. Photobiol. 89, 1413-1416 (2013)

52. S. Thangavel, R. Rajamanikandan, H.B. Friedrich, M. Ilanchelian, B. Omondi, Binding interaction, conformational change, and molecular docking study of $\mathrm{N}$-(pyridin-2-ylmethylene)aniline derivatives and carbazole $\mathrm{Ru}(\mathrm{II})$ complexes with human serum albumins. Polyhedron 107, 124-135 (2016)

53. S. Al-harthi, J.I. Lachowicz, M.E. Nowakowski, M. Jaremko, L. Jarmeko, Towards the functional high-resolution coordination chemistry of blood plasma human serum albumin. J. Inorg. Biochem. 198, 110716 (2019)
54. B. Bhattacharya, S. Nakka, L. Guruprasad, A. Samanta, Interaction of bovine serum albumin with dipolar molecules: fluorescence and molecular docking studies. J. Phys. Chem. B 113, 2143-2150 (2009)

55. N. Venugopal, G. Krishnamurthy, H.S. Bhojya Naik, J.D. Manohara, DNA binding, molecular docking and antimicrobial evaluation of novel azo dye ligand and their metal complexes. J. Inorg. Organomet. Polym. Mater. 30, 2608-2625 (2020)

Publisher's Note Springer Nature remains neutral with regard to jurisdictional claims in published maps and institutional affiliations. 